\title{
El nuevo procedimiento disciplinario de los abogados
}

\author{
Gloria Ortega Reinoso
}

Doctora en Derecho. Profesora de la Universidad de Granada.

1. PLANTEAMIENTO.- 2. CONFIGURACIÓN JURÍDICA DEL DENUNCIANTE.- 2.1. EN EL PROCEDIMIENTO SANCIONADOR COMÚN.- 2.1.1. Doctrina tradicional.- 2.1.2. Crítica a la doctrina tradicional.- 2.1.3. La Ley 30/92.- 2.1.4. El RD 1398/93 (RPS).- 2.1.5. Nueva Doctrina.- 2.2. EN LOS PROCEDIMIENTOS DISCIPLINARIOS.- 2.3. EN EL NUEVO PROCEDIMIENTO DISCIPLINARIO DE LOS ABOGADOS.- 3. LA DENUNCIA.- 3.1. EN LOS PROCEDIMIENTOS SANCIONADORES.- 3.2. EN EL NUEVO PROCEDIMIENTO DISCIPLINARIO DE LOS ABOGADOS.- 4. LA INFORMACIÓN PREVIA.- 4.1. EN EL PROCEDIMIENTO SANCIONADOR COMÚN.4.2. EN EL NUEVO PROCEDIMIENTO DISCIPLINARIO DE LOS ABOGADOS.- 4.2.1. Actuaciones previas sui generis.- 4.2.2. Información previa.- 4.2.3. El denunciante abogado es más interesado.- 5. CONSIDERACIONES FINALES.- 5.1. EL MALTRECHO SECRETO PROFESIONAL.- 5.2. LA NUEVA SITUACIÓN DEL ABOGADO IMPUTADO

\section{PLANTEAMIENTO}

El pasado 25 de junio del 2004 el Pleno del Consejo General de la Abogacía Española (CGAE) aprobó un nuevo Reglamento de Procedimiento Disciplinario (RPD) que será aplicable directamente o, en su caso, con carácter supletorio, en las actuaciones que realicen los Colegios de Abogados, los Consejos de Colegios de las Comunidades Autónomas, y el CGAE para la depuración de la responsabilidad disciplinaria en la que puedan haber incurrido los abogados, los colegiados no ejercientes, y los abogados inscritos en virtud del RD 936/2001 ${ }^{1}$, en caso de infracción de sus deberes profesionales, colegiales, o deontológicos, sin perjuicio de la responsabilidad civil o penal que se les pueda exigir por los órganos jurisdiccionales.

\footnotetext{
${ }^{1}$ RD 936/2001, de 3 de agosto, que transpone la Directiva 98/5/CE, del Parlamento Europeo y del Consejo, de 16 de febrero de 1998, destinada a facilitar el ejercicio permanente de la profesión de abogado en un Estado miembro distinto de aquel en el que se haya obtenido el título.
} 
Se dicta en desarrollo de la Ley de Colegios Profesionales ${ }^{2}$ y del Estatuto General de la Abogacía Española (EGAE) ${ }^{3}$, y adaptado, según indica, a la Ley 30/924 y al Reglamento del Procedimiento para el Ejercicio de la Potestad Sancionadora (RPS) ${ }^{5}$, que se aplicarán en lo no previsto en él ${ }^{6}$, si bien, se aparta de estas normas y de la doctrina constante de los Tribunales Contencioso-Administrativos en muchos de sus aspectos, como veremos a continuación.

El nuevo RPD de los abogados ha entrado en vigor el día 1 de octubre del 2004, sustituyendo al que fuera aprobado por la Asamblea de Decanos del CGAE en sesión de 25 de junio de 1993, modificado el 30 de junio de 1995, aunque, como indica su Disposición Transitoria, "Los expedientes disciplinarios abiertos antes de la entrada en vigor de este Reglamento y que se encuentren en tramitación en dicha fecha se regirán hasta su conclusión por las normas vigentes en el momento de su incoación".

El nuevo RPD de los abogados está transido de una premisa, cual es, la configuración jurídica del denunciante, al que por el solo hecho de la denuncia se le otorga la condición de interesado y parte en el procedimiento disciplinario que regula, lo que condiciona su posición jurídica durante toda la tramitación, sin que esto tenga apoyatura legal alguna, y en contra de la doctrina constante de los citados Tribunales.

${ }^{2}$ Ley 2/1074, de 13 de febrero.

${ }^{3}$ Aprobado por RD 658/2001, de 26 de junio.

${ }^{4}$ Ley 30/1992, de 26 de noviembre, de Régimen Jurídico de las Administraciones Públicas y del Procedimiento Administrativo Común.

${ }^{5}$ Aprobado por RD 1398/1993, de 4 de agosto.

${ }^{6}$ Referencia expresa a tales normas que permite su aplicación, pues, en otro caso, habría de estarse a lo que disponen los arts. 127.3 de la Ley 30/92 y 1.3, pfo. $2^{\circ}$, del RPS, según los cuales, los arts. 127 a 138 de dicha Ley y las disposiciones del citado Reglamento no son de aplicación ni tienen carácter supletorio respecto del ejercicio por las Administraciones Públicas de su potestad disciplinaria. 


\section{CONFIGURACIÓN JURÍDICA DEL DENUNCIANTE}

\subsection{En el procedimiento sancionador común}

\subsubsection{Doctrina tradicional}

Para intervenir en un procedimiento administrativo no basta con la capacidad de obrar. Es necesario algo más. Una aptitud especial que se conoce con el nombre de legitimación, que implica una relación del sujeto con lo que constituye el objeto del procedimiento, esto es, una especial posición del sujeto respecto del acto que ha de dictarse en el procedimiento ${ }^{7}$. La configuración subjetivista de la legitimación, inherente al procedimiento administrativo, conlleva que éste se inicie por quien pide algo para sí, ostentando por ello interés en su resultado.

En los procedimientos administrativos sancionadores el criterio legitimador que tradicionalmente ha permitido al administrado su intervención (no su incoación, que se produce de oficio), incluida la posibilidad de recurso, ha sido la titularidad de un "interés directo", configurado en un principio como un interés "legítimo", pues sólo puede otorgarse protección a intereses conformes al Ordenamiento jurídico ${ }^{8}$, lo que significa que han de estar protegidos por un precepto legal concreto, en contraposición a otros que no son objeto de tal protección"; "personal", pues el acto administrativo ha de afectar de manera particularizada a la esfera jurídica del administrado; y "directo", pues ha de haber una relación inmediata entre la situación creada o derivada

\footnotetext{
${ }^{7}$ La exigencia del requisito procesal de la legitimación se ha declarado compatible con el derecho consagrado en el art. 24.1 CE, que reconducido a sus justos límites prohíbe la indefensión del sujeto. Por lo que, únicamente los requisitos procesales que impidan u obstaculicen esa defensa pueden reputarse inconstitucionales. Entre ellos no se encuentra la legitimación. Si bien, algunas exigencias legitimadoras han tenido que aplicarse con criterio diferente, consecuencia de la interpretación sistemática de los arts. 162.1.b) CE y 48.1, 46.1.b) y DT $2^{a}$ de la LOTC. Así, se ha sustituido el criterio legitimador del "interés directo" por el más amplio del "interés legítimo"; vid., LAFUENTE BENACHES, M., "La legitimación para impugnar actos y disposiciones administrativos después de la Constitución”, REDA, no 42, 1984, pp. 435-457.

${ }^{8}$ Vid., LEGAZ LACAMBRA, L., "Legalidad y legitimidad", $R A P$, no 101 , pp. 5 y ss.

${ }^{9}$ STC 218/1983, de 11 de julio.
} 
del acto administrativo y el administrado. En consecuencia, no ha bastado un interés "indirecto" 10 , ni se ha admitido la "acción popular", que se identifica con el simple interés de la legalidad ${ }^{11}$, y que es excepcional ${ }^{12}$.

La Constitución, en cambio, ha señalado que el interés para que el particular pueda pretender la tutela jurídica de los Jueces y Tribunales ha de ser "legítimo" y "personal", pero no es necesario que sea "directo"13. Siempre que el administrado pueda demostrar la repercusión perjudicial, directa o indirecta, del acto administrativo en su esfera jurídica deberá reconocérsele legitimación, pues en ambos casos será titular de un interés legítimo lesionado, radicando entonces la dificultad en diferenciar el interés indirecto del mero interés por la legalidad ${ }^{14}$.

Por tanto, habrá interés que legitime la intervención del administrado en el procedimiento administrativo cuando de su resolución pueda obtener al-

${ }^{10}$ Cuando el particular pueda obtener de la impugnación del acto administrativo una ventaja o evitar un perjuicio, aunque no exista una relación inmediata entre la situación creada por el acto administrativo y el administrado recurrente, podemos considerar que éste ostenta un "interés indirecto" en la anulación o modificación de aquél, LAFUENTE, cit., p. 443.

${ }^{11}$ Esta es una legitimación ex lege. Su fundamento está en la voluntad del legislador, que puede otorgarla a una categoría determinada de personas, a un sujeto o sujetos concretos, o de forma indiscriminada a cualquier persona (acción popular), para que pueda interponer las acciones que estime pertinentes sin necesidad de alegar ningún tipo de titularidad en la relación jurídica debatida en el proceso.

${ }^{12}$ Sin embargo, GARCÍA DE ENTERRÍA/FERNÁNDEZ RODRÍGUEZ, Curso de Derecho Administrativo, Madrid, Vol. II, 1991, p. 183, entienden que "El reparto del campo sancionatorio entre la Administración y los Tribunales obliga a extender a la primera la acción popular prevista en el artículo 125 de la Constitución y generalizada en el artículo 270 de la Ley de Enjuiciamiento Criminal".

13 Como puso de relieve el TC en su Sentencia 97/1991, de 9 de mayo, "Este Tribunal ha declarado reiteradamente que la expresión «interés legítimo» es más amplia que la de «interés directo» de la Ley de la Jurisdicción Contencioso-Administrativa (STC 60/1982), y como tal resulta identificable con cualquier ventaja o utilidad derivada de la reparación pretendida (ATC 356/1989). Ahora bien, este Tribunal también ha precisado que la expresión «interés legítimo» utilizada en nuestra Norma Fundamental, aun cuando sea un concepto diferente y más amplio que el de «interés directo» ha de entenderse referido a un «interés en sentido propio, cualificado o específico" (STC 257/1988)"; vid., NIETO, A., "La discutible supervivencia del interés directo", $R E D A, \mathrm{n}^{\circ} 12$, pp. 39 y ss.

${ }^{14}$ Vid., LAFUENTE, cit., p. 444. 
gún beneficio, o se le evite un perjuicio ${ }^{15}$, según la posición que adopte: para el que solicita su incoación o comparece a fin de que se dicte existirá interés siempre que la resolución le reporte un beneficio; para el que comparece oponiéndose a la pretensión existirá interés siempre que la situación creada por la resolución le origine un perjuicio, aunque se produzca por vía indirecta o refleja ${ }^{16}$. Beneficio o perjuicio que pueden ser de la más variada naturaleza, civil o administrativo ${ }^{17}$, material o moral $^{18}$, pues lo que se tiene en cuenta es la repercusión o efecto del acto.

Conforme a esta doctrina, el único interesado en el procedimiento sancionador ha sido aquél contra el que se ha dirigido, pues, aun cuando entre la persona totalmente ajena a la infracción y la que resulta perjudicada por ella existe una diferencia cualitativa, no por ello ostenta ésta un interés legítimo; interés que sólo podría cifrarse en el castigo del infractor, ya que la resolución que ponga fin al procedimiento sancionador no admitirá otro contenido que el archivo o la sanción, y de ninguno de los dos se deriva un beneficio para el perjudicado, que, en particular, no ve reparado el perjuicio sufrido. Interés, por tanto, en que se sancione al infractor que no es legítimo, so pena de reconocer relevancia jurídica al "ánimo de venganza"19. Por lo que, en el procedimiento sancionador sólo pueden intervenir dos sujetos, la Administración, que ejercita su ius puniendi, y el inculpado, que hace valer su ius libertate.

15 La STC 143/1987, de 23 de septiembre, señaló que el interés legítimo al que se refiere el art. 24.1 "equivale a la titularidad potencial de una posición de ventaja o de una utilidad jurídica por parte de quien ejercita la pretensión y que se materializaría de prosperar ésta (TC SS 60/1982, 62/1983, 257/1988 y 97/1991, entre otras)”.

${ }^{16}$ La STS de 29 de septiembre de 1997 se refiere a que la relación unívoca entre el sujeto y el objeto que define la legitimación comporta que el acto que en definitiva se dicte "produzca de modo inmediato un efecto positivo (beneficio) o negativo (perjuicio), actual o futuro, pero cierto (STS de 1 de octubre de 1990, Ar. 1454), y presupone por tanto que la resolución administrativa pueda repercutir, directa o indirectamente, pero de modo efectivo y acreditado, es decir, no meramente hipotético, potencial y futuro, en la correspondiente esfera jurídica de quien se persona (STS de 4 de enero de 1991, Ar. 1241). En la misma línea pueden citarse las Ss. de 17 de marzo y 30 de junio de 1995 (Ar. 2387 y 5111) y 12 de febrero de 1996 (Ar. 1567), entre otras muchas".

${ }^{17}$ Vid., STS de 14 de noviembre de 1970.

${ }^{18}$ Vid., SSTS de 18 de noviembre de 1993 y 28 de marzo de 1985.

${ }^{19}$ REQUENA LÓPEZ, T., “¿El ocaso de la concepción del inculpado como único interesado en el procedimiento sancionador?”, RAAP, no 26, 1996, p. 50. 
La posición jurídica del perjudicado por la infracción administrativa en el procedimiento sancionador únicamente ha podido ser la de un denunciante, que se define como aquél que pone en conocimiento de la Administración determinados hechos dando noticia de ellos; actuación con la que se agota su status jurídico, pues no puede formular alegaciones en el procedimiento que se incoe, ni se le notifican los acuerdos que en él se dicten, ni puede recurrirlos.

Los Tribunales han negado a los denunciantes legitimación para exigir la persecución de las infracciones que les han perjudicado y los derechos procedimentales que se reconocen al interesado en sentido legal en un procedimiento administrativo por dos razones básicamente: porque no puede haber un tercero interesado en que la Administración sancione, y porque la potestad sancionadora está delimitada por los intereses públicos que defiende y por los derechos del imputado, que son los únicos que pueden verse afectados ${ }^{20}$, quedando extramuros el resto, aunque haya sujetos perjudicados por la actividad infractora, pero para los que ningún pronunciamiento favorable puede derivarse de la resolución que ponga fin al procedimiento, dado que, como hemos visto, la imposición de una sanción al denunciado no constituye por sí misma la satisfacción de un interés.

La Jurisprudencia insistía en que al tercero o denunciante no se le puede reconocer el derecho a ejercitar una "acusación particular", que no está prevista en el procedimiento administrativo sancionador ${ }^{21}$. Por lo que el tercero perjudicado por la infracción sólo podía ser un denunciante, carente de legitimación en ese procedimiento ${ }^{22}$, pero con una diferencia, aunque única, en relación con el denunciante no perjudicado, y es que al primero se le reco-

${ }^{20} \mathrm{El}$ procedimiento sancionador se contrae exclusivamente "al binomio Administrador-infractor, por lo que, fuera de estas personas, no puede colegirse interés alguno" (STS de 3 de febrero de 1982).

${ }^{21}$ Así lo reitera la STS de 13 de enero de 1994, según la cual, "Que en los procedimientos sancionadores, y concretamente en los disciplinarios, por su naturaleza cuasipenal, la Administración venga obligada a respetar los derechos de defensa del inculpado -cuya participación es consustancial a este tipo de procedimientos- en los términos que establece el artículo 24.2 de la Constitución, y entre ellos el derecho a la presunción de inocencia a que se refiere la demanda, no significa que correlativamente se reconozcan en dicho precepto análogos derechos al denunciante y por ende su cualidad de parte acusadora en aquéllos".

${ }^{22}$ Vid., STS de 23 de enero de 1986, según la cual, "la condición de denunciante es sustancialmente distinta de la de parte interesada, de forma que nunca adquiere este carácter". 
nocía el derecho a que se le comunicara la resolución que pusiera fin al procedimiento $^{23}$, aunque sin ninguna trascendencia jurídica, ya que carecía de legitimación para recurrirla, tanto en vía administrativa como jurisdiccional ${ }^{24}$.

"Las posibilidades de actuación del particular se agotan en la denuncia de la infracción cometida" (STS de 20 marzo de 1992). "Y no siendo parte el denunciante en las diligencias previas informativas carece de acción para instar la prosecución de la actividad sancionadora del Colegio de Abogados ante el que se presentó la denuncia, ni objetar la falta de motivación del acuerdo ordenando el archivo de dichas diligencias, toda vez que ese acuerdo no afecta a su derecho ni interés, sin perjuicio de ejercer las acciones que en el orden civil o penal creyere le corresponden por los actos denunciados que estime procedentes" (STS de 9 de febrero de 1993).

En definitiva, la Jurisprudencia ha negado de forma constante al denunciante (perjudicado o no por la infracción) el carácter de interesado en el procedimiento administrativo sancionador ${ }^{25}$. No hay más interesado que el imputado, al no haber un derecho individual a la sanción, ni ser posible en el marco del procedimiento sancionador el resarcimiento de los daños individuales derivados de la infracción.

\footnotetext{
${ }^{23}$ Vid., entre otras, SSTS de 5 julio de 1977, 16 de marzo de 1982, 28 de noviembre de 1983 , 27 de junio de 1984, y 23 de enero de 1986.

24 Vid., STS 23 de junio de 1997, según la cual, "La consecuencia inmediata de este planteamiento es que, si se niega la condición de parte en el procedimiento administrativo, por falta de interés en él, falta ya una base (en términos sustancialistas) para poder sustentar esa misma condición en un ulterior proceso impugnatorio de actos de aquél, pues el mero dato formal de la existencia de un acto dictado en el procedimiento administrativo no tiene entidad para alumbrar un interés nuevo, diferenciable del inexistente antes".

25 Vid., por todas, la STS de 23 de enero de 1986: "el denunciante de una supuesta infracción... no se convierte en titular de ningún derecho subjetivo ni pone en juego un interés personal o legítimo... que hubiera de encontrar satisfacción adecuada y traducida en algún beneficio o ventaja, puesto que se limita a comunicar a la Administración un proceder que considera irregular, a fin de que se ponga en marcha su actividad investigadora y sancionadora, que... es concluida de oficio por aquélla con una resolución sancionadora o de sobreseimiento, sin más aclaraciones y menos aún de reconocimiento de situaciones individualizadas en favor de personas ajenas al fin perseguido, criterio éste que se recoge por la jurisprudencia, indicando que la condición de denunciante es sustancialmente distinta de la de parte interesada, de forma que nunca adquiere este carácter".
} 


\subsubsection{Crítica a la doctrina tradicional}

Esa postura de los Tribunales ha sido criticada por la Doctrina ${ }^{26}$, pues difícilmente resulta conforme con el Ordenamiento jurídico el negar en todo caso al denunciante la condición de interesado ${ }^{27}$. Hay que admitir, como punto de partida, que puede haber supuestos en los que la actividad infractora afecte de forma negativa, además de al interés público, a intereses particulares, y que pueda afirmarse que sus titulares ostentan un interés legítimo (distinto, por tanto, del cumplimiento de la legalidad y del castigo del infractor) tutelable en el procedimiento sancionador en cuestión ${ }^{28}$.

Si el particular afectado puede obtener un beneficio en el procedimiento sancionador habrá que considerarlo interesado en sentido legal con los derechos que el procedimiento administrativo le reconoce ${ }^{29}$, y entre ellos, el de

\footnotetext{
${ }^{26}$ Vid., GARCÍA DE ENTERRÍA/FERNÁNDEZ RODRÍGUEZ, Curso..., cit.; REBOLLO PUIG, "Interesados y denunciantes en el procedimiento administrativo sancionador", Coord. J. BARNÉS VÁZQUEZ, El procedimiento administrativo en el Derecho comparado, Madrid, 1992, pp. 227 y ss, publicado también en Poder Judicial, nº 29, 1993, pp. 59-78; GARCÍA MANZANO, P., "Comentario al Título IX", AAVV, Comentario sistemático a la Ley de Régimen Jurídico de las Administraciones Públicas y del Procedimiento Administrativo Común, Madrid, 1993; PARADA VÁZQUEZ, R., Régimen Jurídico de las Administraciones Públicas y Procedimiento Administrativo Común, Madrid, 1993, y Derecho Administrativo, I, Madrid, 1995; NIETO, Derecho Administrativo Sancionador, Madrid, 1994; COBREROS MENDANOZA, E., "La posición del denunciante en el procedimiento administrativo sancionador. Nuevas perspectivas", RVAP, no 41, 1995, pp. 761 y ss, y "El reconocimiento al denunciante de la condición de interesado en el procedimiento sancionador", El Derecho Administrativo en el umbral del siglo XXI. Homenaje al Profesor Dr. D. Ramón Martín Mateo, Valencia, 2000, www.tirantonline.com; HUERGO LORA, A., "La desigualdad en la aplicación de potestades administrativas de gravamen: remedios jurídicos”, RAP, no 137, 1995; REQUENA, “¿El ocaso de la concepción del inculpado..., cit., pp. 39-63; TOLA RÚA, M.A., "La consideración jurídica del denunciante en el procedimiento sancionador”, Actualidad Administrativa, nº 31, 1999.
}

${ }^{27}$ REBOLLO, "Interesados y denunciantes..., cit., p. 61, señala que "de que el denunciante no se convierta por esa sola condición en interesado no se infiere de ninguna forma que no lo pueda ser si realmente concurren en él otras circunstancias".

${ }^{28}$ Según COBREROS, "El reconocimiento al denunciante..., cit., "qué duda cabe que de la revocación de una licencia otorgada para realizar una actividad, constitutiva de la sanción prevista por ejercer indebidamente y con perjuicio de terceros dicha actividad, puede producir un efecto beneficioso en tales terceros (que han podido actuar como denunciantes o no)".

${ }^{29}$ REBOLLO, "Interesados y denunciantes..., cit., p. 73, indica que "En los casos en que la infracción haya concretado de alguna forma sus efectos antijurídicos sobre sujetos determinados podrá detectarse un interés legítimo de los perjudicados. No cabe dar una respuesta general positiva y será necesario atender a las circunstancias de cada caso, pero desde luego no puede excluirse por hipótesis como en ocasiones se ha hecho". 
exigir la persecución de la infracción y el de ser parte en el procedimiento con todas las garantías procedimentales. Son entonces posibles dos tipos de denunciantes: el denunciante-simple, que sólo formula la denuncia, y el denunciante-cualificado, o interesado, si efectivamente demuestra la titularidad de un interese legítimo protegible en el procedimiento sancionador de que se trate $^{30}$.

El perjudicado sigue sin ostentar por el solo hecho de serlo un interés legítimo que lo convierta en interesado, pues, como se ha expuesto, el interés en que se sancione al infractor no es legítimo. Y sin que pueda buscarse un paralelismo con el proceso penal, en el que todo perjudicado tiene derecho a la reparación material del daño, so pena de defender la generalización de la acción popular en el procedimiento sancionador, que no es admisible, salvo excepciones, a diferencia de lo que ocurre en el proceso penal, en el que encuentra fundamento en la mayor valoración de los bienes jurídicos protegidos por el Derecho Penal ${ }^{31}$, de forma que el acusador particular puede acumular su pretensión civil a la penal. Sin embargo, el perjudicado por la infracción administrativa no puede participar en el procedimiento sancionador con la pretensión de que la resolución sancionadora declare, además del contenido propiamente punitivo, la responsabilidad civil del infractor en su favor. Para obtener el resarcimiento, restitución, o indemnización tendrá que acudir al proceso civil declarativo correspondiente; la Administración sólo puede actuar como una instancia independiente para declarar la responsabilidad civil tendente a reparar sus propios perjuicios patrimoniales ${ }^{32}$.

\footnotetext{
${ }^{30}$ PARADA, Régimen Jurídico..., cit., p. 279, argumenta que la doctrina del TS que niega al denunciante el carácter de interesado en el procedimiento "valdrá realmente para supuestos en que el denunciante no tiene ninguna otra vinculación con los hechos que el de su conocimiento, ni otro interés que el de cumplir en abstracto con su deber de colaboración ciudadana; pero la solución no debe ser la misma cuando, además de que se instruya o no el procedimiento y de que se resuelva en uno u otro sentido, se deriven para él beneficios concretos, como las primas de denuncia, o la prevención de daños para el denunciante o su entorno, como pudiera entenderse en el caso de denuncia de conductas que perjudican como puede ser el caso de denuncia de infracciones urbanísticas".
}

31 TORÍO LÓPEZ, A., "Injusto penal e injusto administrativo (presupuestos para la reforma del sistema de sanciones)", Estudios sobre la Constitución Española. Libro Homenaje a Eduardo García de Enterría, III, Madrid, 1991, pp. 2529 y ss.

${ }^{32}$ GARBERÍ LLOBREGAT, “El art. 3 del RD 1398/93”, El Derecho administrativo sancionador, Valencia, 2002. 
En definitiva, y a diferencia de la postura tradicional, hay que admitir que el denunciante puede ser interesado en los procedimientos sancionadores al menos en dos ocasiones: 1) Si el legislador ha consagrado en la regulación sectorial la acción popular para exigir la observancia de sus disposiciones, en cuyo caso el denunciante por el solo hecho de la denuncia se considera beneficiario de la presunción legal de interés legítimo (o de la no necesidad de aducirlo y probarlo) y, en consecuencia, interesado y parte en el procedimiento ${ }^{33}$. Presentada una denuncia en virtud de esta acción popular, el órgano competente tiene que iniciar el procedimiento sancionador, a salvo las denuncias inverosímiles o carentes de contenido infractor, y el denunciante puede someter al control jurisdiccional una eventual inactividad de la Administración; y 2) Si el denunciante es el perjudicado por la infracción y la regulación sectorial ha previsto junto a las medidas meramente represivas otras de carácter reparador del daño causado de las que pueda beneficiarse ${ }^{34}$, puesto que sí es legítimo el interés en la reparación del daño sufrido, para cuya satisfacción deberá constituirse en parte por medio de la personación, como han de hacerlo los interesados en los demás procedimientos administrativos ${ }^{35}$.

${ }^{33}$ COBREROS, "El reconocimiento al denunciante..., cit.

${ }^{34}$ No obstante, algunos autores estiman que al perjudicado hay que reconocerle en todo caso la condición de interesado en el procedimiento sancionador; PARADA, Derecho Administrativo, cit., p. 565, le reconoce esa condición al denunciante que tenga derecho a premio, al perjudicado y al que vaya a obtener una indemnización "(existe alguna diferencia entre estos dos últimos sujetos?)"; a esta idea responde la Ley 2/1998, de 20 de febrero, de la Potestad Sancionadora de las Administraciones Públicas de la Comunidad Autónoma del País Vasco, en cuya Exposición de Motivos se lee que "El artículo 30 y el 35 pretenden introducir el equivalente a la acusación particular del proceso penal. No se encuentra motivo alguno para limitar la virtualidad del concepto general de interés legítimo en el procedimiento administrativo sancionador. El ciudadano no tiene derecho a castigar, pero, en cuanto víctima posible del ilícito penal o administrativo, tiene un claro interés en solicitar el ejercicio del poder público punitivo y en participar en el procedimiento previsto para encauzar tal ejercicio. La infracción administrativa puede perjudicar los derechos e intereses individuales tanto como el delito o la falta penales (amén del perjuicio al interés general siempre presente), por lo que no se alcanza a comprender la causa de la limitación consistente en que en el procedimiento administrativo sancionador únicamente estén presentes el interés general y el individual del imputado...", que analiza COBREROS, "El reconocimiento al denunciante..., cit.

${ }^{35}$ REQUENA, “¿El ocaso de la concepción del inculpado..., cit., p. 51, concluye que "puede afirmarse que siempre que la infracción cause perjuicios de cualquier índole a los particulares y que la sanción (excepcionalmente) o las medidas que cortejen a aquélla (normalmente) permitan reparar aquéllos, ha de reconocerse la condición de interesados a esos agraviados". 


\subsubsection{La Ley $30 / 92$}

La Ley 30/92 no contiene una regla, expresa ni tácita, de la que inducir que solo el inculpado es interesado en los procedimientos sancionadores. Y, por el contrario, admite como principio la posible existencia de otros interesados si en ellos concurre alguna de las situaciones legitimadoras que describe en su art. 31. Este precepto confiere legitimación para actuar en el procedimiento administrativo:

A) A "quienes lo promuevan como titulares de derechos o intereses legítimos individuales y colectivos". Situación legitimadora que está pensada para los procedimientos administrativos iniciados a instancia de parte (art. 70 Ley 30/92), y no para los iniciados de oficio, entre los que se encuentran los procedimientos sancionadores, que son promovidos e impulsados por los órganos administrativos competentes (arts. 69 y 74.1 Ley 30/92), a los que no cabe calificar de interesados, como tampoco puede serlo el inculpado que, lógicamente, no promoverá un procedimiento en su contra, y ni siquiera los terceros afectados en sus derechos e intereses por la infracción, porque tampoco ellos promueven e impulsan este tipo de procedimiento.

B) A "los que, sin haber incoado el procedimiento, tengan derechos que puedan resultar afectados por la decisión que en el mismo se adopte". En esta situación legitimadora se encuentra el imputado en los procedimientos sancionadores, cuyos derechos fundamentales (de presunción de inocencia, de defensa, etc.) se encuentran afectados desde que el procedimiento se dirige en su contra como presunto infractor, sin perjuicio de los personales o patrimoniales que también puedan serlo si la resolución es sancionadora. En tal sentido, el art. 13.2 RPS califica expresamente al inculpado como interesado. Y también pueden encontrarse los terceros que ostenten derechos subjetivos (no simples intereses legítimos) que puedan resultar afectados por la resolución, lo que en la práctica resulta difícil, dado que la resolución que ponga fin al procedimiento sancionador no podrá contener una declaración de responsabilidad civil a su favor.

c) Las personas "cuyos intereses legítimos, individuales o colectivos, puedan resultar afectados por la resolución y se personen en el procedimiento en tanto no hay a recaído resolución definitiva", que tampoco existirán en un procedimiento sancionador en tanto la resolución sólo pueda acordar el archivo o la imposición de una sanción. No así, cuando dicha resolución pueda decidir otras medidas capaces de afectar a intereses legítimos, como la reparación del daño provocado por la infracción, y el perjudicado se haya personado en el procedimiento 
(personación que puede ser expresa, por una declaración en tal sentido al tiempo de formular la denuncia o con posterioridad, o tácita, por su intervención en el procedimiento incoado).

En definitiva, la Ley 30/92 deja abierta la puerta a interesados distintos del inculpado en los procedimientos sancionadores porque sean titulares de un derecho subjetivo, o más fácilmente de un interés legítimo, que pueda resultar afectado por la resolución que le ponga fin y se hayan constituido en parte.

\subsubsection{El RD 1398/93 (RPS)}

Aparentemente el RPS admite interesados distintos del imputado en el procedimiento sancionador común que regula.

En primer lugar se trata del denunciante que acompaña su denuncia de una solicitud de iniciación del procedimiento sancionador (art. 11.2 RPS). Sin embargo resulta, que su interés se limita a la incoación del procedimiento, cuando es el interés en la resolución el que otorga la condición de interesado, y que esa solicitud no vincula a la Administración para iniciar el procedimiento sancionador (art. 11.1 y 2 RPS). El único efecto jurídico de dicha solicitud es la obligación que surge para la Administración de notificarle la decisión que adopte al respecto (arts. 11.2 y 13.2 RPS).

En segundo lugar se trata de esos otros interesados a los que se refiere el art. 3.4, cuando habla de garantizar "la defensa del imputado y la de los intereses de otros posibles afectados", y el art. 13.2, cuando indica que el acuerdo de iniciación del expediente habrá de notificarse "al denunciante, en su caso, y a los interesados, entendiendo en todo caso por tal al inculpado". Término, interesados, que reitera a lo largo de su articulado.

Ahora bien, el único significado de tales referencias es que el RPS no excluye que puedan intervenir en el procedimiento sancionador interesados distintos del inculpado siempre que efectivamente lo sean. Si bien, no es a él a quien corresponde su determinación. No son las normas procedimentales, sino las materiales, las que han de establecer cuándo un particular es interesado en un procedimiento y cuándo no. Y a tal efecto hay que recurrir en primer lugar al art. 31 de la Ley 30/92, que establece con carácter general, para todos los procedimientos administrativos, cuándo se ostenta la condición de interesado, sin que el RPS imponga ninguna reducción en el procedimiento sancionador que él regula ${ }^{36}$.

\footnotetext{
${ }^{36}$ REQUENA, cit., pp. 56-57.
} 
Se mantiene, por tanto, que el perjudicado por la infracción no se transforma automáticamente en interesado. Para que lo sea es necesario que sea titular de un interés que pueda verse satisfecho en el procedimiento sancionador, lo que a su vez dependerá de que las leyes que disciplinan los diversos ámbitos sectoriales, especialmente las sancionadoras que tipifican las infracciones y las sanciones, contemplen medidas reparadoras entre las consecuencias de la infracción. Si la sanción a imponer o las medidas que lleve aparejada pueden reparar el perjuicio causado por la infracción a un particular deberá reconocérsele su condición de interesado; ni el interés en el cumplimiento de la legalidad (que fundamenta la acción popular, que es excepcional) ni el interés lesionado son intereses legítimos en el procedimiento sancionador, pero sí el de la reparación de la lesión sufrida, siempre que el procedimiento sea cauce idóneo para su satisfacción.

En este sentido, el art. 22 del RPS aporta un dato en orden a la legitimación del perjudicado por la infracción, al establecer con carácter general la posibilidad de que la resolución del procedimiento sancionador imponga medidas reintegradoras o reparadoras, pues, aun cuando la limita a que los daños los haya sufrido la Administración, puede ocurrir que estos hayan alcanzado a los particulares y que la reparación de aquellos conlleve la de estos, en cuyo caso habrá que reconocerles la condición de interesados en sentido legal.

\subsubsection{Nueva Doctrina}

Posteriormente, el TS ha matizado que la solución no puede ser igual respecto de todos los denunciantes y en todos los procedimientos sancionadores, sino que debe ser casuística, de modo que no es aconsejable ni una afirmación ni una negación indiferenciadas para todos los casos, pues puede haber denunciantes en los que concurra la condición de interesados porque aleguen y prueben un interés legítimo, concretado en la posibilidad de obtener una ventaja de la resolución que ponga fin al procedimiento sancionador, lo que dependerá de que ésta pueda contener pronunciamientos distintos de la mera imposición de sanción al imputado que efectivamente les favorezcan, ya que, como sigue argumentando el TS, la sanción del imputado, o lo que es igual, la satisfacción del denunciante de que se castigue al denunciado -interés moral, único que le resta-, no es bastante para fundamentar su legitimación. Se trata de un "simple interés", insuficiente para configurar el concepto técnico de interesado, para el que se requiere un "interés legítimo", y cuya confusión llevaría a la legitimación pública, que no es lo pretendido por el art. 24 CE 37 .

\footnotetext{
37 Vid, por todas, la STS de 8 de febrero del 2001: "Con relación a tal cuestión de la legitimación activa del recurrente contra el Acuerdo de Archivo de las diligencias informativas, adoptado
} 
Por lo que, aun cuando el TS ha avanzado en el sentido de admitir la posible existencia de denunciantes que sean interesados, porque efectivamente aleguen y prueben un interés legítimo, y no por el solo hecho de interponer la denuncia o de resultar perjudicados por la infracción, sigue fiel a la tesis beneficio/perjuicio en la esfera jurídica del denunciante.

\subsection{En los procedimientos disciplinarios}

Si bien esta nueva orientación jurisprudencial permite distinguir entre denunciantes-no interesados y denunciantes-interesados en los términos vistos, esta distinción carece de virtualidad en los procedimientos disciplinarios, en los que, dado el contenido de las sanciones a imponer y que éstas no se acompañan de medidas reparadoras, es imposible que el eventual perjudicado pueda encontrar algún tipo de satisfacción admisible jurídicamente; se concluye, entonces, que el interés que pudiera ostentar no se dilucida en el procedimiento disciplinario ${ }^{38}$.

Y es que, el fundamento de la potestad disciplinaria difiere del de la potestad sancionadora. Ésta es una especie del género ius puniendi del Estado, cuyo objetivo es castigar las infracciones del orden jurídico general no calificadas como delito por el ordenamiento penal y proteger a los miembros de la sociedad en su conjunto, mientras que la potestad disciplinaria se asienta en un poder de coacción que precisa la Administración para proteger su propia organización frente a determinadas conductas de sus miembros ${ }^{39}$. Distinción

por la Comisión Disciplinaria del Consejo General del Poder Judicial, una reiteradísima jurisprudencia de esta Sala... ha venido a expresar que, partiendo de que la respuesta al problema de la legitimación debe ser casuística, de modo que no es aconsejable ni una afirmación ni una negación indiferenciadas para todos los casos, la Sala entiende que la existencia de la legitimación viene ligada a la de un interés legítimo de la parte que se lo arroga, siendo que la clave para determinar si existe o no ese interés legítimo en el proceso de impugnación de una resolución del Consejo General del Poder Judicial, dictada en expediente abierto en virtud de una denuncia de un particular por una hipotética responsabilidad de un Juez, debe situarse en el dato de si la imposición de una sanción puede producir un efecto positivo en la esfera jurídica del denunciante o puede eliminar una carga o gravamen en esa esfera, y ser así, en cada caso, y en función de lo pretendido, como pueda darse la contestación adecuada a tal cuestión, no siéndolo la de que la imposición de la sanción constituye por sí misma la satisfacción de un interés".

${ }^{38}$ REQUENA, “¿El ocaso..., cit., p. 43.

${ }^{39}$ En este sentido, la STS de 20 de julio de 1988 declaró que “...el derecho disciplinario persigue, más que el restablecimiento del orden social quebrantado, la salvaguarda del prestigio y dignidad de la Administración y la garantía de la correcta actuación de los funcionarios", y la de 7 de mayo de 1986 que la finalidad del régimen disciplinario "es tutelar tan peculiar organización y su orden interno, haciéndolo discurrir por una concreta relación personal de sujeción". 
que recoge tanto la Ley 30/92, que excluye el régimen disciplinario de la regulación que ella contiene sobre el procedimiento sancionador (art. 127.3), como el RPS (art. 1.3, pfo. $2^{\circ}$ ).

Así, del procedimiento disciplinario seguido contra los abogados sólo pueden predicarse efectos para el abogado inculpado, bien porque se declare su responsabilidad disciplinaria y se le imponga la oportuna sanción, bien porque se declare que no ha incurrido en ella con su consiguiente archivo. En el primer caso la resolución agota su contenido en la imposición de la sanción: ni el apercibimiento, ni la suspensión en el ejercicio de la Abogacía por el periodo que haya de acordarse, ni la expulsión, únicas consecuencias de la infracción, pueden satisfacer el interés del eventual perjudicado. Como pone de relieve la STS, entre otras muchas, de 8 de febrero de 2001, "el procedimiento disciplinario ni puede interferir un proceso en curso, si lo está, ni alterar las resoluciones que en éste hayan recaído, ni es instrumento de satisfacción de los intereses debatidos en ese proceso, por lo que no cabe así que esos mismos intereses puedan operar como base de legitimación del denunciante, en cuanto interesado, en su caso, en obtener que se imponga una sanción en el caso contemplado, ya que entre el interés legitimador del proceso previo y el hipotético interés en obtener dicha sanción, existe una diferencia cualitativa indudable, un salto lógico indiscutible”.

Pero es que, si pese a ello el denunciante solicitara algo distinto de la mera exigencia de responsabilidad disciplinaria que pudiera representar un beneficio para su esfera jurídica, precisamente con la intención de poder alegar y probar un interés propio que le legitime para ser parte en el procedimiento disciplinario, resultaría que, si bien esto sería favorable a su legitimación al menos en vía de principio, también lo sería la incompetencia del órgano que conoce del procedimiento disciplinario para pronunciarse sobre esa otra petición, como puso de manifiesto la STS de 20 de noviembre de $2000^{40}$.

${ }^{40}$ STS de 20 de noviembre de 2000: "el planteamiento que se hace en la demanda, y, por remisión de la misma, en los diversos escritos de denuncia que ha presentado ante diferentes Organismos, parece exceder -hasta donde resulta posible comprenderlos, dado lo sumamente confuso de su redacción- de la mera petición de medidas sancionadoras, para internarse en la pretensión de que el Consejo, de alguna forma, intervenga en la corrección de las particulares resoluciones judiciales que, según su criterio, se han dictado en su perjuicio. Es por eso que en este proceso puede entenderse que la parte actora pide algo que efectivamente podría representar un beneficio para su esfera jurídica. Ahora bien, este motivo favorable a la legitimación del demandante es el que, a su vez, determina inexorablemente la consecuencia de que el recurso sea desestimado, porque si se examinan las denuncias del actor, éste en realidad no hace más que manifestar su desacuerdo con los comportamientos y decisiones de cuantas personas han interveni- 
Y es que, como resumió la STSJ de Castilla-La Mancha, Sala de lo Contencioso-administrativo, Sección 2ª , de 1 de marzo de 1999, "Debe tomarse nota de que el Tribunal Supremo se está refiriendo, en estos casos, a recurrentes que, como en el nuestro, se consideraban directamente perjudicados por la actitud denunciada, y, pese a ello, les deniega la legitimación. La doctrina indicada supone dar por buenas las siguientes afirmaciones, que se encuentran explícita o implícitamente contenidas en la misma: a) La facultad de denunciar un hecho perseguible de oficio por la Administración no concede al denunciante la condición de parte interesada, ni la posibilidad por tanto de recurrir, incluso cuando, sin perjuicio de que la Administración lo pueda perseguir de oficio, el hecho ha causado o puede haber causado un perjuicio directo al denunciante; b) El ejercicio de acciones disciplinarias sólo concluye en su caso con la imposición de una sanción al denunciado, pero no con la reparación material al denunciante, ni en el sentido de una indemnización ni en el de la revocación de la actuación jurisdiccional realizada; c) El mero interés moral que, por tanto, resta al denunciante, de que se sancione al denunciado, no es suficiente para fundamentar su legitimación”.

\subsection{En el nuevo procedimiento disciplinario de los abogados}

Si se repasa la tramitación del nuevo procedimiento disciplinario de los abogados se comprueba que reserva una intervención al denunciante paralela a la del abogado imputado. Así, habrá que notificar al denunciante a efecto de posibles recursos: el acuerdo de archivo ab initio de la denuncia (art. 6.1, pfo. $3^{\circ}$ ); el que ponga fin a un eventual periodo de información previa que decrete su archivo o la imposición de una sanción por infracción leve (art. 7.4, pfo. $2^{\circ}$ ); los acuerdos que adopte el instructor en materia de prueba (art. 11.6); y la resolución que ponga fin al expediente disciplinario (art. 16.7).

Y está prevista su participación en todos los trámites que conforman el nuevo procedimiento disciplinario. Unas veces el RPD se refiere a él utilizando el término denunciante, y otras lo incluye junto con el imputado en términos comprensivos de ambos, según su planteamiento, como interesados o partes. Así, habrá que dar traslado al denunciante de las alegaciones y pruebas propuestas por el inculpado para que formule las que le interesen (art. 10.1); se

do en relación con sus peticiones y recursos. Pues bien, dejando de lado las quejas o denuncias relativas a corporaciones (Federaciones de fútbol y Comités de árbitros) y Letrados, sobre los que el Consejo General del Poder Judicial carece por completo de competencia disciplinaria alguna y centrando el tema debatido en las alegaciones referidas a las decisiones jurisdiccionales, es claro que al afirmar el Consejo su incompetencia para actuar en el ámbito de lo estrictamente jurisdiccional, no hizo otra cosa que dar cabal cumplimiento al artículo 117 de la Constitución”. 
abrirá un periodo probatorio cuando, entre otros casos, lo haya solicitado el denunciante (art. 11.1 y 5); se le notificará el acuerdo del instructor ordenando la práctica de pruebas (art. 11.1, último pfo., y 4); e igualmente se le notificará, para que presente alegaciones y documentos, la propuesta de resolución (art. 14.1), el resultado de las actuaciones complementarias (art. 16.2), y cuando el órgano decisor considere que la infracción reviste mayor gravedad que la indicada por el instructor (art. 16.4). Alude a los interesados cuando se refiere a la resolución que pone fin al expediente disciplinario (art. 16.1), y a las partes en relación con la aportación de documentación nueva (art. 14.2). En dos ocasiones se vale del término interesado (en singular), lo que, sin embargo, no significa que esté excluyendo al denunciante, pues, en cuanto a la recusación, el conocimiento de la identidad del instructor y del secretario puede no ser simultáneo (art. 9.3), y en relación con la modificación de lo inicialmente fijado dice que se notificará al interesado en la propuesta de resolución (art. 13.2), de la que, como hemos visto, también hay que dar traslado al denunciante (art. 14.1). Por último, obsérvese que hace uso del término $e x-$ pedientado para referirse al interesado-imputado por oposición al interesadodenunciante, cuando resulta que también éste es expedientado, en la medida en que interviene en el expediente que regula el nuevo RPD, que por ello debió prescindir de tal término, que sí tiene sentido en el resto de procedimientos disciplinarios, en los que el único interesado y expedientado es el imputado.

En definitiva, el nuevo RPD de los abogados otorga al denunciante, sea o no el perjudicado por la infracción, por el solo hecho de interponer la denuncia la condición de interesado y parte en el procedimiento disciplinario que regula, y en coherencia con tal configuración lo tiene en cuenta en todos y cada uno de los trámites, garantizándole el principio de defensa y el de contradicción. En este sentido, el precepto más expresivo es quizá el art. 14.1, según el cual, "La propuesta de resolución se notificará al expedientado y al denunciante, indicándoles la puesta de manifiesto del expediente, y concediéndoles un plazo improrrogable, de diez días para que puedan alegar ante el Instructor cuanto consideren conveniente en su defensa" (defensa, por tanto, también del denunciante).

Al respecto conviene recordar que, a la vista de los preceptos de la Constitución relativos a la configuración del poder sancionador de la Administración, el Tribunal Constitucional elaboró una doctrina general, contenida por vez primera en su Sentencia 18/1981, de 8 de junio, conforme a la cual, los principios penales son de aplicación, con ciertos matices, a las sanciones administrativas. Así, la preceptiva audiencia del imputado en el seno del procedimiento sancionador constituye un corolario necesario del derecho consti- 
tucional de defensa, que requiere para la imposición de sanciones administrativas la existencia de un procedimiento contradictorio en el que aquél tenga la posibilidad de aportar y proponer el material probatorio que estime pertinente y de formular las alegaciones que a su derecho convengan.

A esa finalidad responde el trámite de audiencia y vista del procedimiento, regulado en el art. 19.1 del RPS, que evita tener que dar traslado a los interesados de todas y cada una de las actuaciones que se van realizando dentro del procedimiento en orden al esclarecimiento de los hechos para que puedan emitir su opinión sobre ellas, lo que complicaría la tramitación, comprometiendo la eficacia de la acción administrativa. Trámite de audiencia que debe cumplirse en sus justos términos, a fin de evitar la indefensión que trata de enervar, y que por ello sólo está previsto para los interesados-parte, que, como venimos repitiendo, en los procedimientos disciplinarios sólo pueden serlo los imputados.

\section{LA DENUNCIA}

\subsection{En los procedimientos sancionadores}

Conforme al art. 11.1 del RPS, "Los procedimientos sancionadores se inician siempre de oficio, por acuerdo del órgano competente, bien por propia iniciativa o como consecuencia de orden superior, petición razonada de otros órganos o denuncia" (en igual sentido los arts. 69.1 de la Ley 30/92 y 6.1 del hoy derogado RPD de los $\operatorname{abogados}^{41}$ ).

Por tanto, los procedimientos sancionadores se inician siempre de oficio por acuerdo del órgano competente, que no está vinculado por la denuncia (a salvo su contenido), lo que influye en algunos institutos jurídicos. Así, en el plazo de prescripción de la infracción, que no se interrumpe por la interposición de la denuncia, como tampoco se cuenta desde ella el plazo que determina la caducidad del procedimiento.

La denuncia no tiene otro efecto "que el de poner en conocimiento de la Administración la comisión de hechos supuestamente ilícitos, con el fin de

${ }^{41} \mathrm{El}$ art. 6.1 del hoy derogado RPD decía que "El procedimiento se iniciará de oficio por resolución de la Junta de Gobierno resolución que se adoptará por propia iniciativa a petición razonada del Decano o por denuncia”. 
que se ponga en marcha su actividad investigadora y sancionadora" (STS 27 junio 1984), pero sin que en nuestro Ordenamiento jurídico haya disposición alguna que imponga a la Administración la obligación de incoar expediente sancionador a instancia de parte. El art. 11.2 RPS insiste en que la denuncia no vincula al órgano competente para iniciar el procedimiento sancionador.

Efectivamente, la denuncia no obliga al órgano competente a su incoación, el cual, no sólo no debe iniciarlo cuando se trate de denuncias inverosímiles, disparatas o faltas de contenido infractor (pues los poderes públicos no puedan abusar de su inicial posición de preeminencia como titulares de la potestad sancionadora) ${ }^{42}$, sino que ante el resto puede estimar, en virtud del margen de discrecionalidad que ostenta en este momento, que no es oportuno su inicio ${ }^{43}$. Discrecionalidad que, no obstante, no juega cuando la infracción es grave, ni cuando en los casos de menos gravedad es denunciada por un interesado en sentido legal. Pero sin que, incluso en tales casos, se limiten las facultades que la Administración tiene para comprobar la veracidad de los hechos denunciados ${ }^{44}$.

42 Vid., STC 111/1995, de 4 de julio, conforme a la cual, cuando el órgano judicial entienda razonadamente que los hechos imputados, suficientemente descritos en la querella, carecen de ilicitud penal, el derecho a la jurisdicción que ejerce el denunciante y el querellante no conlleva el de apertura de una instrucción.

${ }^{43}$ Niegan este margen de discrecionalidad, REBOLLO, "Interesados y denunciantes..., cit., p. 75; GARCÍA/FERNÁNDEZ, Curso..., cit., p. 183; PARADA, Derecho Administrativo, cit., p. 493.

${ }^{44}$ Se trata del discutido tema de si la Administración debe regirse por el principio de legalidad, en cuyo caso el ejercicio de la potestad sancionadora es una actuación debida u obligada, de forma que producida una infracción la Administración necesariamente tiene que iniciar el correspondiente procedimiento sancionador, o por el principio de oportunidad, en cuyo caso goza de un margen de libre apreciación (o discrecionalidad) sobre si ejercitar o no sus potestades sancionadoras. Pues bien, aun cuando hay que partir del principio de legalidad, la realidad de la Administración, cuyos medios materiales y personales suelen ser insuficientes para perseguir todos los ilícitos, unido a que puede considerar más eficaz determinadas políticas permisivas, aconsejan que tenga un cierto margen de decisión en cuanto al ejercicio de la potestad sancionadora de la que es titular, sin que su falta de ejercicio suponga siempre un incumplimiento (y finalmente una ilegalidad), ya que, en resumidas cuentas, la potestad sancionadora no es mas que un instrumento del que el Ordenamiento jurídico dota a la Administración para que pueda servir con objetividad los intereses generales (art. 103.1 CE), a diferencia de los órganos jurisdiccionales penales, que tienen como única y exclusiva misión la de juzgar los ilícitos penales y hacer ejecutar lo juzgado (art. 117.3 y 4 CE). Principio de oportunidad, por tanto, pero con ciertas limitaciones: 1) No podrá reconocerse margen alguno de discrecionalidad atendiendo a la gravedad del hecho constitutivo de la infracción y a la entidad del riesgo originado o del daño efectivamente producido; y 2) En los restantes casos (leves infracciones o consecuencias): a) La discrecionalidad se referirá sólo al momento previo al ejercicio de la potestad sancionadora; b) La dis- 
Y es que, como hemos visto, el denunciante por el hecho de la denuncia, es decir, por poner en conocimiento del órgano competente unos hechos que pueden constituir una infracción, no adquiere la condición de interesado en sentido legal, ni legitimación para ser parte en el procedimiento sancionador. Por lo que ninguna consideración tiene en el mismo, salvo que en su denuncia haya incluido una petición de iniciación, en cuyo caso, y según la legislación vigente (arts. 11.2 y 13.2 RPS y 42.1 Ley 30/92), tiene derecho a que la Administración le comunique el acuerdo que haya adoptado, de inicio o no del procedimiento. La resolución denegatoria ha de ser expresa (art. 42.1 Ley 30/92) y motivada (art. 54.1.a y f Ley 30/92). Si, no obstante, la Administración incumple esta obligación, y guarda silencio, habrá que entender, dado que es un supuesto que no encaja en la regulación del silencio administrativo de la Ley $30 / 92^{45}$, y transcurrido el plazo de tres meses (que es el genérico que actúa por defecto o en ausencia de otro específico, art. 42.3 Ley 30/92), que la Administración ha desestimado la solicitud de iniciación. Inactividad que quedará huérfana de control jurisdiccional, pues, según la legislación citada y la doctrina constante del Tribunal Supremo, este denunciante-peticionario carece de legitimación para impugnarla.

$\mathrm{Si}$, por el contrario, el denunciante tiene la condición de interesado, porque efectivamente ostente algún interés legítimo tutelable en el procedimiento sancionador en cuestión, podrá exigir su iniciación y constituirse en parte mediante la personación, si así le interesa. Si este denunciante-interesado presenta una denuncia verosímil y debidamente formulada con la inequívoca petición de que se incoe procedimiento sancionador la Administración no puede negarse a iniciarlo. Si, no obstante, no lo abre, aquél tiene derecho a una resolución expresa y motivada. Y ante su falta, habrá que entender, como en el caso anterior, que su solicitud de iniciación ha sido desestimada. Acuerdo presunto de desestimación que, a diferencia del caso anterior, podrá recurrir el denunciante, que es un interesado, legitimado para ser parte, dada la técnica conversora de la inactividad material en inactividad jurídico-formal ${ }^{46}, \mathrm{y}$

crecionalidad queda sometida al control de la jurisdicción contencioso-administrativa; y c) No hay discrecionalidad cuando la infracción es denunciada por un interesado, sin perjuicio de las facultades que tiene la Administración de comprobar la veracidad de los hechos denunciados; vid., COBREROS, "El reconocimiento al denunciante..., cit.; SANZ RUBIALES, I., "Revocación de sanciones administrativas por motivos de oportunidad", RAP, no 148, 1999, pp. 359 y ss; NIETO, Derecho administrativo sancionador, cit., p. 144, quien adopta la postura más radical a favor del principio de discrecionalidad.

45 COBREROS, cit; GÓMEZ PUENTE, M., La inactividad de la Administración, Pamplona, 1997, p. 403.

${ }^{46}$ Vid., NIETO, "La inactividad de la Administración en la LJCA de 1998", Justicia Administrativa, $\mathrm{n}^{\circ}$ extraordinario, 1999 , pp. 45 y ss. 
que es un acto que imposibilita la continuación del procedimiento (arts. 107.1 Ley 30/92 y 25.1 LJCA) ${ }^{47}$. De estimarse el recurso, la jurisdicción contencioso-administrativa anulará el acuerdo de no incoación y ordenará a la Administración que inicie el correspondiente procedimiento para depurar las posibles responsabilidades administrativas a que haya lugar ${ }^{48}$.

\subsection{En el nuevo procedimiento disciplinario de los abogados}

De forma diversa a lo analizado, el art. 6.1, pfo. $1^{\circ}$, del nuevo RPD de los abogados dice que "El procedimiento se iniciará por resolución de la Junta de Gobierno, o de quien tenga delegada tal competencia... La resolución se adoptará de oficio o por denuncia", que es tanto como afirmar que el nuevo procedimiento disciplinario de los abogados no tiene por qué iniciarse siempre de oficio, ya que también puede serlo a instancia de parte por denuncia, aunque advierte que es necesario el previo acuerdo de incoación del órgano competente, lo que lejos de implicar una contradicción no hace mas que poner de relieve la dificultad de que un procedimiento sancionador pueda iniciarse por solicitud del particular, cuando es absolutamente imprescindible una actividad administrativa procedimental.

El citado precepto no dice, como debiera, que el procedimiento disciplinario que regula se ha de iniciar siempre de oficio, pero sí deja claro que la denuncia no lo apertura de forma automática, ya que es necesario un acuerdo de incoación del órgano competente. Prueba de ello son los arts. 6.1, pfo. $4^{\circ}$, sobre que podrá "requerirse al denunciante para que complete, aclare o aporte la documentación o antecedentes que sean necesarios para determinar la admisión a trámite de la denuncia"; 7.1, "La Junta de Gobierno podrá iniciar el procedimiento abriendo un periodo de información previa..."; 8.1, "La apertura del expediente disciplinario será acordada por la Junta de Gobierno..."; 4.1, "El procedimiento disciplinario se impulsará de oficio en todos sus trámites”; y 16.8, que en relación con la notificación de la resolución del expediente disciplinario señala que "si el procedimiento se hubiese iniciado como consecuencia de denuncia también se realizará dicha notificación al que la hubiese formulado".

${ }^{47}$ COBREROS, cit., estima que habrá que entender que el plazo de prescripción de la infracción "ha quedado paralizado, reanudándose si el denunciante-interesado no recurre tal desestimación presunta. Esta última previsión parece necesaria puesto que, en caso contrario, todo el esfuerzo del denunciante podría verse finalmente frustrado y la Administración, consciente o inconscientemente, beneficiaría nuevamente al posible infractor".

${ }^{48}$ Vid., STS de 3 de junio de 1998. 
Ahora bien, de haber denuncia, ésta vincula al órgano competente, que debe dictar un acuerdo de incoación, excepto si la denuncia carece manifiestamente de contenido deontológico, es inverosímil o mendaz ${ }^{49}$, únicos supuestos en los que el órgano competente podrá acordar su archivo ab initio. Así se desprende del art. 6.1, pfo. $3^{\circ}$, del nuevo RPD de los abogados, a cuyo tenor, "Cuando se considere que la denuncia carece manifiestamente de contenido deontológico o es inverosímil o mendaz podrá decretarse su archivo sin más trámite. La resolución que disponga el archivo se notificará al denunciante para que, en su caso, deduzca los recursos correspondientes".

Sin embargo resulta que, conforme a la teoría general de los procedimientos sancionadores, el órgano competente para acordar su inicio no está vinculado por la denuncia. Su incoación sólo puede decidirla cuando entienda que hay pruebas o al menos indicios de haberse cometido una infracción. Que la denuncia esté relacionada con la materia deontológica, si no hay indicios de infracción, no es suficiente para su apertura. Y cuando faltan esos indicios, no es que el órgano competente podrá archivar la denuncia, sino que tiene que hacerlo inexorablemente, pues en otro caso podría estar incurriendo en una situación de abuso del derecho (caracterizado, a tenor del art. 7.2 CC, por el daño para tercero, en este caso el abogado imputado, implícito en todo procedimiento disciplinario).

\section{LA INFORMACIÓN PREVIA}

\subsection{En el procedimiento sancionador común}

Como se adelantaba, únicamente debe darse trámite a las denuncias que comuniquen la existencia de una infracción administrativa con cierta dosis de verosimilitud y con el contenido mínimo que describe el art. 11.1.d) RPS ${ }^{50}$; sólo las que contengan los datos necesarios para una adecuada defensa, y no

49 Término, mendaz, que es similar al anterior (inverosímil), pero con una carga peyorativa, "1. Adj. Mentiroso", DRAE, Ed. Electrónica, 21.1.0 (Espasa Calpe, 1995), que bien podía haberse evitado.

${ }^{50}$ Art. 11.d), "Las denuncias deberán expresar la identidad de la persona o personas que las presentan, el relato de los hechos que pudieran constituir infracción y la fecha de su comisión y, cuando sea posible, la identificación de los presuntos responsables". 
otras, deben promover el ejercicio por la Administración de su potestad sancionadora. Esas otras deben archivarse sin más trámite ${ }^{51}$.

Si la denuncia está bien formulada, pero de ella y de la documentación adjunta, en su caso, no se derivan suficientes indicios de infracción que justifiquen la apertura del procedimiento sancionador, lo oportuno es abrir una "información previa" (o "actuaciones previas", o "información reservada", según las distintas denominaciones), regulada en los arts. 12.1 del RPS y 69.2 de la Ley 30/92, pues no toda notitia infractionis ha de ocasionar la apertura de procedimiento sancionador, sino sólo aquélla que facilite el conocimiento de la comisión de una infracción administrativa.

Dice el art. 12.1 RPS que "Con anterioridad a la iniciación del procedimiento se podrán realizar actuaciones previas con objeto de determinar con carácter preliminar si concurren circunstancias que justifiquen tal iniciación..." 52 .

Por tanto, la apertura de un periodo de información previa tiene carácter discrecional, pues se configura como una facultad administrativa ${ }^{53}$, pero con el límite de que la denuncia carezca de un mínimo de veracidad o, en el otro extremo, de que existan indicios racionales manifiestos de comisión de una infracción susceptible de sanción, en cuyo caso su inicio constituirá una dilación innecesaria e inútil ${ }^{54}$, ya que "su naturaleza extraprocedimental sin las capitales garantías del mismo: singularmente, de publicidad y contradicción, hace que deba ser usada de manera estricta" (STSJ de Aragón de 20 de noviembre de 1993).

El carácter diferenciado y previo al procedimiento sancionador de estas actuaciones se asienta en su naturaleza, ya que sólo sirven para fundamentar la decisión sobre la apertura o no de aquél, sin que en ningún caso tengan la

51 “...el Juez, cuando se aprecie de forma evidente que los hechos denunciados carezcan de relevancia penal, deba realizar, con la mayor premura, las actuaciones necesarias para el inmediato archivo de la causa, como en el presente caso se ha hecho", STC 138/1997, de 22 de julio.

52 Art. 69.2 Ley 30/92, “Con anterioridad al acuerdo de iniciación, podrá el órgano competente abrir un periodo de información previa con el fin de conocer las circunstancias del caso concreto y la conveniencia o no de iniciar el procedimiento".

53 Vid., SSTS de 11 de febrero de 1986 y de 3 de noviembre de 1992.

${ }^{54}$ Vid., STS de 8 de julio de 1991. 
virtualidad de comenzarlo ${ }^{55}$. Ambos aspectos han sido subrayados por el TS en Sentencia, entre otras, de 27 de febrero de 2001, cuando indica que estas investigaciones previas "no forman parte del expediente sancionador, no son propiamente expediente administrativo, sino un antecedente que la ley faculta a la Administración para llevar a cabo y a la vista de su resultado acordar lo procedente; esto es, el archivo de las actuaciones o la orden de incoación del expediente..." ${ }^{56}$; constituyen en su conjunto un procedimiento accesorio, de carácter preliminar o preparatorio, respecto del procedimiento disciplinario, ya que su finalidad es depurar de manera previa, mediante las averiguaciones indispensables, si concurren indicios suficientes para la iniciación de éste ${ }^{57}$.

El carácter preliminar de la información previa tiene relevancia en el cómputo del plazo de prescripción de la infracción y en el de caducidad del procedimiento sancionador. Respecto del plazo de prescripción, y aun cuando la Jurisprudencia y la Doctrina han sido vacilantes, hoy por hoy no cabe duda que la información previa no lo interrumpe, ya que, según el art. 132.2, pfo. $2^{\circ}$, de la Ley 30/92, sólo "interrumpirá la prescripción la iniciación, con conoci-

55 "La denuncia no inicia el procedimiento sancionador, ni tampoco la información reservada, sino que tal iniciación tiene lugar precisamente por el acto que acuerda la incoación”, STS de 4 de junio de 1990.

${ }^{56}$ Continúa la STS de 27 de febrero de 2001, que "Se trata, por tanto, de actuaciones que tienen lugar extramuros del procedimiento sancionador propiamente dicho, cuya finalidad no va más allá de una apreciación acerca de si, efectivamente, se han producido o no los hechos de que se tiene noticia, y, en su caso, personas que hayan intervenido en aquellos así como las circunstancias concurrentes en la producción de aquellos y la intervención de éstas en los mismos, para poder así, concluir, si hay motivos razonables para iniciar el procedimiento sancionador... En definitiva, las llamadas actuaciones previas constituyen una actuación administrativa preliminar y de carácter contingente que trata de comprobar si prima facie puede considerarse que hay una base seria para abrir el procedimiento sancionador propiamente dicho".

${ }^{57}$ STS de 5 de mayo de 1998: "No puede, por consiguiente, constituir un dato relevante para admitir la recurribilidad del acto el hecho de que pusiera fin a las diligencias informativas. Éstas, aun teniendo una unidad formal, constituyen en su conjunto un procedimiento accesorio, de carácter preliminar o preparatorio, respecto del procedimiento disciplinario, ya que su finalidad es depurar de manera previa, mediante las averiguaciones indispensables, si concurren indicios suficientes para la iniciación de éste, pero no decidir sobre la existencia o no de responsabilidad disciplinaria, de tal suerte que el acto que pone fin a dichas diligencias sólo tiene carácter definitivo, haciendo imposible la continuación del procedimiento, cuando acuerda el sobreseimiento, pero no cuando resuelve iniciar el procedimiento disciplinario". 
miento del interesado, del procedimiento sancionador..., en el que, como hemos visto, no se incluye la información previa ${ }^{58}$. Y en cuanto a la caducidad, ésta se refiere únicamente al procedimiento sancionador (art. 42.3.a Ley 30/92), por lo que la información previa no está sujeta a este instituto.

\subsection{En el nuevo procedimiento disciplinario de los abogados}

\subsubsection{Actuaciones previas sui generis}

Dice el art. 6.1, pfo. $4^{\circ}$, del nuevo RPD de los abogados que "Podrá igualmente, con carácter previo y por plazo de diez dias, requerirse al denunciante para que ratifique su denuncia y, en su caso, complete, aclare o aporte la documentación o antecedentes que sean necesarios para determinar la admisión a trámite de la denuncia y señale domicilio a efecto de notificaciones. El requerimiento contendrá la advertencia de que, expirado el plazo sin haberse atendido, podrá decretarse el archivo de la denuncia".

Varios son los aspectos que deben ser objeto de comentario:

1) En relación con la ratificación de la denuncia, que no está prevista en el RPS ni en la Ley 30/92, no parece que su exigencia deba quedar al arbitrio del órgano competente. El nuevo RPD debería haber sido más contundente a la hora de establecer este requisito en todos o en los supuestos que especificara, y de predicar las consecuencias de su omisión, y no decir que se podrá requerir al denunciante para que ratifique su denuncia y que expirado el término sin haberlo atendido podrá decretarse el archivo de la denuncia. Términos que crean inseguridad, salvo que se entienda que la falta de ratificación de la denuncia es en realidad intrascendente en los procedimientos disciplinarios, que se inician y tramitan de oficio y en los que el denunciante no es interesado. Justificación que, sin embargo, no sirve en el nuevo procedimiento disciplinario de los abogados, en el que, según hemos concluido, se otorga la condición de interesado al denunciante, en cuyo caso, no es que tenga que ratificarse si para ello es requerido, sino que debería personarse a fin de constituirse en parte conforme a la teoría general de la legitimación, y a la que no

\footnotetext{
58 Vid., STS de 13 de marzo del 2002, según la cual: "La interrupción de los plazos prescriptivos, cierto es, no se produce por la tramitación de diligencias reservadas o informaciones previas, sino por la apertura del procedimiento disciplinario mediante el correspondiente acuerdo de incoación, que debe ser formalmente notificado al interesado para que ese efectos interruptivo se produzca. Por consiguiente, si el acuerdo de incoación del procedimiento sancionador y el posterior acuerdo de nombramiento de Instructor y Secretario no se notificaron en debida forma a la interesada, no pueden surtir ningún efecto de interrupción de la prescripción”.
} 
hace referencia alguna el nuevo RPD de los abogados, ya que también le otorga la condición de parte por el hecho de su denuncia.

2) En cuanto a que el denunciante "complete, aclare o aporte la documentación o antecedentes que sean necesarios para determinar la admisión a trámite de la denuncia", esto parece excesivo que se realice en este trámite previo a la admisión de la denuncia, aun cuando el plazo previsto sea corto, siendo más lógica su ubicación en un periodo de información previa, cuya finalidad es, precisamente, conocer las circunstancias del caso concreto y la conveniencia o no de iniciar el procedimiento disciplinario, a cuyo fin podrá requerirse al denunciante dicha documentación y explicaciones complementarias en su condición, no de interesado, que no debería serlo, pero sí de testigo cualificado de la infracción denunciada, si efectivamente lo es porque, por ejemplo, haya resultado perjudicado por ella.

Todo ello, tal y como dispone el art. 12.1 del RPS para los procedimientos sancionadores, y prevee el art. 7.1 del nuevo RPD de los abogados para un momento posterior, cuando señala que el Ponente de la información previa realizará de oficio cuantas actuaciones considere necesarias, "recabando los $d a$ tos e informaciones que estime puedan ser relevantes para determinar la posible existencia de responsabilidades dignas de investigación".

Por lo que, ningún sentido tienen esas actuaciones sui generis previas a la admisión de la denuncia, salvo retardar la adopción de un acuerdo de archivo o de inicio del procedimiento disciplinario, que alarga en el tiempo la interrupción del plazo de prescripción de la infracción denunciada, en su caso.

\subsubsection{Información previa}

Conforme a los arts. 6.1, pfo. $2^{\circ}$, del nuevo RDP de los abogados, " $E l$ inicio del mencionado procedimiento podrá dar lugar a la apertura de un periodo de información previa o a la apertura del expediente disciplinario...", y 7.1, "La Junta de Gobierno podrá iniciar el procedimiento abriendo un periodo de información previa...", resulta que el periodo de información previa es parte del procedimiento disciplinario, aunque anterior, en su caso, al expediente disciplinario. La nota discordante se encuentra en la Disposición Transitoria, que parece admitir que la información previa no es parte del procedimiento disciplinario, al referirse a "Los expedientes disciplinarios abiertos antes de la entrada en vigor de este Reglamento..." (y no a los procedimientos disciplinarios). 
A salvo la nota discordante, y congruente con su planteamiento, el nuevo RPD de los abogados declara que el acuerdo de apertura de información previa interrumpe el plazo de prescripción de la falta que le haya dado origen (art. 7.1). Pero, de forma incongruente con él, excluye el periodo de información previa del instituto de la caducidad, que sólo refiere al expediente disciplinario, pues, según su art. 8.7, pfo. 1ํ, "el expediente disciplinario deberá resolverse en el plazo máximo de seis meses", y sin que regule un plazo máximo para el periodo de información previa, como sí contenía el hoy derogado RPD, que lo cifraba en un mes, resultando, además, que ni el RPS ni la Ley 30/92 señalan plazo a este periodo, del que también se derivan consecuencias negativas para el abogado denunciado, pese a que ni siquiera hay suficientes indicios de que haya cometido una infracción deontológica. Información previa que, por tanto, es de duración indefinida, justificada por la imposibilidad de determinar a priori el momento en el que el órgano competente va a tener los elementos de juicio indicativos de la procedencia de iniciar o no el procedimiento disciplinario, pero que, aún así, no debe extenderse en el tiempo ${ }^{59}$.

Del citado art. 8.7, pfo. $1^{\circ}$, llama la atención la primera parte, "Salvo que legalmente esté establecido otro plazo el expediente disciplinario deberá resolverse...", cuando resulta que es la Ley, en concreto la Ley 30/92, dada la reserva de ley en materia de procedimiento administrativo que consagra el art. $105 \mathrm{CE}$, la que permite que el procedimiento sancionador esté regulado por norma reglamentaria (art. 134.1 Ley 30/92), que bien puede establecer plazos de caducidad diferentes al previsto en la Ley 30/92, dado que la caducidad no se ve alcanzada por esa reserva material de ley, reducida a la predeterminación de los principios básicos, siendo susceptible de regulación reglamentaria en consideración al carácter esencialmente reglamentario de la materia procedimental y a su naturaleza netamente adjetiva ${ }^{60}$.

Añade el art. 16.8 del nuevo RPD de los abogados que "Si no hubiese recaido resolución transcurrido seis meses desde la apertura del expediente disciplinario,... se declarará la caducidad, sin perjuicio de su nueva incoación si no hubiese prescrito la

\footnotetext{
${ }^{59}$ Sin perjuicio de que a tenor del art. 91.3 del EGAE, "La prescripción se interrumpirá por la notificación al colegiado afectado del acuerdo de incoación de información previa a la apertura de expediente disciplinario, reanudándose el cómputo del plazo de prescripción si en los tres meses siguientes no se incoa expediente disciplinario o éste permaneciere paralizado durante más de seis meses, por causa no imputable al colegiado inculpado".

${ }^{60}$ HERNÁNDEZ GONZÁLEZ, F., La caducidad del procedimiento administrativo, Madrid, 1998, p. 270.
} 
infracción". Al respecto procede hacer dos comentarios: 1) Según dicho precepto, el dies ad quem para que opere la caducidad es aquél en el que se dicta la resolución, cuando la Ley 30/92 incluye en dicho plazo su notificación (art. $\left.42.2^{61}\right)$; y 2) Producida la caducidad, lo único que puede acordarse es el archivo del procedimiento caducado, si bien, y en tanto no haya prescrito la infracción cabe abrir un segundo procedimiento por los mismos hechos y contra los mismos sujetos.

Por último, y de forma también incongruente con que la información previa forme parte del procedimiento disciplinario, el nuevo RPD de los abogados no permite la intervención en esa primera parte del denunciante, que reserva para el expediente disciplinario; al denunciante sólo se le participará la adopción del acuerdo de inicio del procedimiento disciplinario abriendo un periodo de información previa, el cual no es susceptible de recurso alguno (art. 7.1). Por el contrario, se establece obligatoria la intervención del abogado denunciado; aspecto que, sin embargo, no prevee el RPS ${ }^{62}$, que deja libertad sobre el contenido de las actuaciones que se estimen convenientes.

\subsubsection{El denunciante abogado es más interesado}

Dice el art. 7.3 del RPD de los abogados que "Cuando el denunciante sea Abogado y la denuncia se interponga contra otro Abogado, colegiado ejerciente o Abogado inscrito, por presunta vulneración de deberes u obligaciones hacia éste como companero de profesión, el Ponente dará cuenta al Decano para que éste realice una labor de mediación si lo estima conveniente. Alcanzada la mediación a satisfacción del denunciante se propondrá el archivo de la información sin más trámite’. Conforme a ese precepto, la satisfacción del denunciante-abogado en el supuesto que describe produce el archivo de la información previa, aun cuando el abogado denunciado haya incurrido en una infracción disciplinaria, incluso muy grave.

Son necesarias las siguientes reflexiones:

61 Art. 42.2 Ley 30/92, "El plazo máximo en el que debe notificarse la resolución expresa será el fijado por la norma reguladora del correspondiente procedimiento. Este plazo no podrá exceder de seis meses salvo que una norma con rango de Ley establezca uno mayor o así venga previsto en la normativa comunitaria Europea”.

62 Vid., STS 5 de octubre de 1992: "En cuanto a la información reservada no es posible pretender que se oyera al señor C. N., pues la misma supone una actividad depuradora o de tamiz en los órganos colegiados para evitar la decisión de abrir o no un expediente, pero no puede pretender equipararse esta actividad a la puramente disciplinaria con un expediente". 
1) Dado que el nuevo RPD de los abogados considera que la información previa es parte del procedimiento disciplinario, no se acierta a comprender por qué la posibilidad que analizamos se contempla únicamente en esa primera fase, que además puede no existir, y no durante todo el procedimiento disciplinario. Y, además, deja sin resolver cómo se articula la mediación cuando el abogado denunciado pertenece a la Junta de Gobierno de algún Colegio de abogados, o es el propio Decano, en cuyo caso la competencia para la iniciación, tramitación y resolución de la información previa y del expediente disciplinario corresponde al Consejo de Colegios de la Comunidad Autónoma y en su defecto al CGAE (arts. 7.2 y 8.5).

2) Es inimaginable la satisfacción a la que se refiere, pues la única consecuencia que puede derivar del procedimiento disciplinario, del que según el RPD forma parte la información previa, es el archivo o la imposición de una sanción al abogado denunciado, y no otra; y paralelamente, del acuerdo que pone fin a la información previa, disponiendo bien su archivo bien la apertura de expediente disciplinario o la imposición de una sanción por infracción leve, tampoco puede derivarse beneficio alguno para el denunciante. Argumento que, precisamente, es el que impide considerar al denunciante, cualquiera que sea su condición profesional, interesado en el procedimiento disciplinario.

3) La exculpación del denunciante carece de efectos en los procedimientos disciplinarios, que se inician y tramitan de oficio, y que el órgano competente tiene que aperturar cuando existen indicios racionales manifiestos de infracción disciplinaria ${ }^{63}$. Mediación que, en consecuencia, tiene sentido sólo al margen del procedimiento disciplinario, aunque sea con carácter previo a fin de evitarlo ${ }^{64}$.

${ }^{63}$ Vid., STS de 26 de mayo de 1987, según la cual, "La exculpación de los denunciantes posterior al inicio del expediente, no puede afectar a la responsabilidad del demandante ya que el interés público, colegial y profesional de los Arquitectos, no puede quedar a merced de una retractación o perdón de las personas lesionadas por la conducta irregular del sancionado, al que no se le restringe por la normativa Deontológica aplicable ninguno de los derechos y libertades fundamentales comprendidos en el título I de la Constitución, sino que por el contrario fortalece el prestigio de una profesión y la justa estimación de la labor profesional de cada Colegiado sin privilegios o ventajas para ninguno y se garantiza el interés del cliente que solicita los servicios de un arquitecto".

${ }^{64}$ En este sentido, dice el art. 79 del EGAE que "El abogado que reciba el encargo de promover actuaciones de cualquier clase contra otro sobre responsabilidades relacionadas con el ejercicio profesional, deberá informar al Decano del Colegio para que pueda realizar una labor de mediación, si la considera oportuna, 
4) El distinto tratamiento entre el denunciante-abogado y el denunciante-no abogado, al que no se le ofrece igual posibilidad de satisfacción (aun cuando ésta es en sentido técnico imposible), y del imputado denunciado por un abogado o por un no abogado, al que no se le reconoce la posibilidad de archivo tras la hipotética satisfacción del denunciante (lo que tiene aún más trascendencia), resulta discriminatorio. Y es que el denunciante, sea o no abogado, y cualquiera que sea la infracción denunciada, carece de interés legítimo en el procedimiento disciplinario: es, en todo caso, un no interesado; y la condición de imputado no guarda relación alguna con la del denunciante, aunque sea abogado.

Y esto, aun cuando se ha intentado justificar como legítimo el interés corporativo profesional, que atribuiría a los abogados denunciantes la condición de interesados en los procedimientos disciplinarios seguidos contra sus colegas denunciados. En este sentido se ha defendido que son titulares de intereses legítimos aquellos sujetos que "por ser los destinatarios de una regulación sectorial, son titulares de un interés propio, distinto del de cualquier ciudadano, por lo que tienen un interés legítimo en que los poderes públicos actúen de acuerdo con el ordenamiento cuando con motivo de la persecución de fines de interés general, inciden en el ámbito de tal interés propio, aun cuando la actuación de que se trata no les ocasione, en concreto, un beneficio o un perjuicio inmediato, sea de carácter moral o material” ${ }^{\prime 5}$.

Argumento que está en la base de la Sentencia del TSJ de Castilla-La Mancha de 7 de febrero de 2000, que entendió que el denunciante, un profesional colegiado, ostentaba un interés legítimo propio, ya que "en el caso de conseguir la incoación de un expediente disciplinario y, en caso de proceder, la imposición de una sanción, el hoy recurrente obtendría, por un lado, un evidente beneficio, por vía directa y también por la eliminación de una carga o gravamen, ya que la hipotética sanción podría conllevar... la expulsión del Colegio o la suspensión del ejercicio de la profesión, entre otras medidas; lo cual,

aun cuando el incumplimiento de dicho deber no pueda ser disciplinariamente sancionado". Precepto que por tanto se refiere a actuaciones de cualquier clase, y no sólo al ejercicio de acciones como dice el art. 12.3 del Código Deontológico de la Abogacía Española, aprobado por el Pleno del CGAE en sesión de 27 de septiembre de 2002, modificado en sesión del 10 de diciembre siguiente, pero que las limita a que haya recibido el encargo de promoverlas, a diferencia de lo que dispone el citado art. 12.3, según el cual, "El Abogado que pretenda iniciar una acción, en nombre propio o como Abogado de un cliente, contra otro compañero por actuaciones profesionales del mismo, habrá de comunicarlo previamente al Decano, por si considera oportuno realizar una labor de mediación".

65 GÓMEZ-FERRER, "Derecho a la tutela judicial y posición jurídica peculiar de los poderes públicos”, REDA, nº 33, 1982, pp. 189-190. 
obviamente, supondría para el actor disminución -o supresión, en su caso-, de la competencia, con el consiguiente beneficio económico”.

No obstante, no lo entiende así la Sentencia del TS, entre otras, de 28 de noviembre del 2003, según la cual, "Establecido que la noción de interés legítimo es identificable, como ha dicho este Tribunal, «con cualquier ventaja o utilidad jurídica derivada de la reparación pretendida-sentencia de 27 de julio de 1993-», de los antecedentes fácticos recogidos en la sentencia impugnada en el caso que enjuiciamos, la esfera jurídica personal y profesional del abogado recurrente en modo alguno se ve afectada por una eventual imposición de una sanción disciplinaria a todos o algunos de los miembros de la Junta de Gobierno del Colegio de Abogados de Valladolid..."66.

\section{CONSIDERACIONES FINALES}

\subsection{El maltrecho secreto profesional}

Conforme al art. 14.1 del nuevo RPD de los abogados, el denunciante tiene derecho a la vista del expediente, lo que no sólo carece de apoyatura legal, pues en los procedimientos disciplinarios no hay más interesado que el imputado, sino que, además, puede vulnerar derechos.

El abogado denunciado en el ejercicio de su derecho de defensa puede haber relatado hechos o desvelado datos de la parte contraria, o del Abogado de ésta, o conversaciones mantenidas con éste, ignorados hasta este momento por el denunciante, y que debe seguir ignorando, al estar protegidos por el secreto profesional.

No hay argumento que justifique la lesión que al secreto profesional, y a otros posibles derechos en cascada, puede provocar la vista del expediente por el denunciante, cuando ni siquiera se produce un conflicto de intereses, puesto que ningún derecho de éste está en juego. Y es que, por más que se empeñe el nuevo RPD de los abogados en decir lo contrario, la ausencia de interés del denunciante se extiende a todos los extremos de la actuación administrativa.

\footnotetext{
${ }^{66}$ Vid., también, STS de 27 de enero de 1989, que negó que el interés profesional corporativo sea suficiente para otorgar legitimación.
} 
Ahora bien, tampoco debe despreciarse la condición de testigo cualificado del denunciante si efectivamente lo es, porque haya resultado perjudicado por la infracción o por otra razón, al que el Ponente en la información previa $^{67}$ y el Instructor en el expediente disciplinario deberán dar la oportunidad de presentar cuantas alegaciones, documentos y testimonios sean necesarios para el esclarecimiento de los hechos, a fin de llevar a cabo con responsabilidad la actividad que a cada uno corresponde, pero sin que por ello se convierta en interesado; sigue siendo un tercero ajeno al procedimiento disciplinario.

\subsection{La nueva situación del abogado imputado}

En definitiva, el nuevo RPD de los abogados convierte a cualquier denunciante en interesado y parte del procedimiento que regula sin fundamento jurídico alguno. Pero, por más participación que de al denunciante, éste no puede conseguir nada en dicho procedimiento, a salvo que se sancione al abogado imputado, interés en que esto ocurra que, como se ha reiterado, no es legítimo, ni le convierte en interesado y parte.

Por el contrario, con la nueva regulación: se ponen en peligro principios básicos de la Abogacía, como el secreto profesional; se complica extraordinariamente el procedimiento, lo que puede desbordar de trabajo a los instructores, con la repercusión que esto tiene para los Colegios de abogados; y se incrementa la incertidumbre y desasosiego de los abogados denunciados, que también tendrán que dedicar más tiempo a defenderse, haciendo frente a las constantes alegaciones y pruebas del denunciante, aumentando así los perjuicios que todo procedimiento disciplinario conlleva para el imputado.

En fin, este nuevo procedimiento disciplinario se aparta de la doctrina legal y jurisprudencial, no beneficia al denunciante, pero perjudica a los abogados imputados y a sus Colegios.

\footnotetext{
${ }^{67}$ La obligatoriedad de su designación es otra novedad del vigente RPD de los abogados (art. 6).
} 